\title{
Orpheus and Pickleherring in the Kremlin: The "Ballet" for the Tsar of February 1672
}

\author{
Claudia Jensen and Ingrid Maier \\ Claudia Jensen, Dept. of Slavic Languages and Literatures, Box 353580, University of Wash- \\ ington, Seattle, Washington USA; cjensen@uw.edu. Ingrid Maier, Uppsala University, Dept. of \\ Modern Languages, Box 636, S-75126 Uppsala, Sweden; ingrid.maier@moderna.uu.se
}

\begin{abstract}
This article identifies and describes a pivotal event in the formation of the Russian court theatre: a performance in February 1672 for the Russian royal family given by a small group of foreign residents in Moscow. This performance (and another that followed in May) was the direct catalyst for the formation of Tsar Aleksej Michajlovičs court theatre in October 1672. By examining a series of contemporary published accounts (printed newspapers and the 1680 work by Jacob Rautenfels) and unpublished diplomatic dispatches, we have not only been able to pinpoint the date for this event (16 February 1672), but also establish the important connections between Western theatrical practice and the beginnings of staged theatre in Russia. Because some of the characters (or their actions) featured in this first Western-style performance appeared later in Tsar Aleksej's regular court theatre (especially the stock comic figure Pickleherring), our work not only rewrites the pre-history of Russian theatre, but also contextualises the performances that followed. More broadly, the documents we use (some of which are newly discovered) show the importance to cultural historians of the communications revolution in Early Modern Europe, with its emphasis on the regular transmission of current news and information through newspapers and diplomatic dispatches, sources that have rarely been used for studies of early Russian culture.
\end{abstract}

Keywords: Russian court theatre, Muscovy, Pickleherring, seventeenth-century newspapers, diplomatic reports, Tsar Aleksej Michajlovič, Jacob Rautenfels (Reutenfels) 


\section{Introduction: Previous Scholarship}

The marvelous events that took place in the Kremlin on 17 October 1672 have long been known to scholars. This is the date of the opening night of Tsar Aleksej Michajlovič's court theatre - a sumptuous retelling of the biblical story of Esther performed by foreign youths resident in Moscow and which included costumes, singing, instrumental music, sets, and comic interludes. The event, prepared especially for the tsar and a limited audience, marks the beginnings of Western-style theatre in Muscovy, the opening act of a long tradition that was to flower during the eighteenth century and, of course, beyond. ${ }^{1}$

In studying this important event, previous historians have relied almost entirely on a set of Muscovite payment records and directives, published as a group by the historian Sergej Bogojavlenskij (1914). These documents, in combination with the account by Jacob Rautenfels (Reutenfels 1680) ${ }^{2}$ about his earlier experiences in Muscovy, set out the generally accepted series of events: the tsar (through the head of his Diplomatic Chancery, Artamon Sergeevič Matveev) sent a messenger abroad to find theatrical specialists and musicians; meanwhile, driven by Tsar Aleksej's impatience to begin, the government recruited actors and a playwright from the foreign community living in Moscow. Thus, on that memorable opening night in October 1672, the tsar, his family, and other high-ranking members of the aristocracy watched the court's first play, The Play of Artaxerxes (Ahasuerus; Artakserksovo dejstvo), in a ten-hour (!) performance. ${ }^{3}$ The play was written by the pastor of Moscow's Lutheran community, Johann Gottfried Gregorii, and performed by boys and young men from the Foreign Quarter (Nemeckaja sloboda). The performance was so successful that it inaugurated a series of plays in what ended up being a rotating repertoire, performed in several different venues, generally in the

1 Liturgical drama, specifically a reenactment of the story of the three boys in the fiery furnace (Daniel 3), performed (generally) on the Sunday of the Forefathers, was known in Russia. Its heyday was in the 1620 s and 1630 s, lingering on into the next decade, and it did feature flamboyant stage effects and specially prepared music. The latest performance we know of is from the mid-1660s (in Vologda; see Relation 1669, 104-105), and such performances are also mentioned as past traditions in Reutenfels (1680,216-217; Russian version in Skazanija 1906, 168).

2 On the spelling of this author's name see below, section 1 .

3 The ten-hour figure and also the date, 17 October, is from Rinhuber $(1883,29)$ : "Acta est haec ipsa in die $17^{\mathrm{mo}}$ Octobris anni 1672. Quam rem admiratus magnus Czar decem horis imobilis $[s i c]$ adspexit." 
early spring and in the fall. These lasted until Aleksej died suddenly in January 1676; at his death, there were several plays in production that never saw the light of day. About a dozen play titles or subjects are known, and about half survive in written texts. ${ }^{4}$

This theatrical interlude has been the subject of many types of scholarly inquiry: historians have situated it within the context of Muscovite court culture; theatre specialists have hunted for appropriate models in Western theatrical and school drama traditions; and linguists have examined the rich textual sources - the first play, for example, is preserved in both German and Russian texts, both of which, intriguingly, contain transliterated Hebrew passages for a series of psalm incantations. Other scholars have focused on these performances as emblematic of Tsar Aleksej's intellectual curiosity and interest in the West, and as important precursors to the innovations introduced by his son and eventual successor, Peter I, "the Great". All of this work has been illuminating, but it has never answered - or even clearly posed - a crucial question: was there a specific stimulus that sparked Aleksej's interest in theatre?

The answer to this question, in brief, is yes: our research has uncovered two linked performances in the spring of 1672 that introduced the tsar to Western-style staged entertainment and that led directly to the establishment of his own theatre several months later. ${ }^{6}$ In this article, we will discuss the first of these two performances, which took place in February 1672 and was organized by Matveev; we will discuss the second of these productions in a separate article, where we will also survey the characters and the performers in greater detail (Jensen and Maier, forthcoming). The main aim of the present article is to introduce our sources, both in English translation and in the original languages. We begin by re-examining Jacob Rautenfels' influential published description of the Muscovite theatre, after which we introduce new sources from Western collections that provide context for his writing as well as additional information on these early performances.

4 All of the play texts have been published in Pervye p'esy 1972 and in the following volume of the same series.

5 In addition to the introductory essays in Pervye p'esy 1972, see, e.g., Cholodov 1983 and 2000, Robinson 1974 and 1976, and - for a summary in English and additional review of the voluminous literature relating to the court theater, which is outside the scope of the present article - Jensen 2009. A linguistic study is in Schellenberger 1993.

6 Some of the sources we discuss below were mentioned briefly in Jensen 2009; the presentation here expands considerably and corrects several errors. 


\section{Source One: Jacob Rautenfels as an Eyewitness to a Theatre Presentation in Moscow}

Jacob Rautenfels was born in Mitau (Courland), probably in the later 1640s; he entered the Danzig gymnasium in 1664 (Tering, forthcoming). His father, Bartholomäus Meyer, who worked in the legal profession, had been ennobled as von Rautenfels in 1645 (ibid.). In the context of the Russian theatre, the most important fact concerning Jacob Rautenfels' life is that he spent about two years in Moscow in the early 1670s, from 1670 to $1672 .{ }^{7}$ During his time in Moscow he lived in the house of the tsar's personal physician, Dr.Johann(es) Coster von Rosenburg (Stensen 1952, 42). ${ }^{8}$ Rautenfels is listed as a plemjannik ('nephew' in modern Russian) ${ }^{9}$ in one source, but we have not been able to verify any familial relationship between the two men. At any rate, Rautenfels must have had some sort of employment while in Moscow. He was not in the service of the tsar (as were almost all of the other resident foreigners) and he may have worked as a private tutor for the doctor's younger children (at the time of Rosenburg's arrival in Moscow, in 1667, he had five sons and one daughter; Dumschat 2006, 477). Rautenfels might have studied at a university prior to his years in Moscow (we know that he was in Cracow in 1667). ${ }^{10}$

7 The exact time of his arrival in Moscow is not known, but since he says in his book that he had seen the tsar's second wife twice as a maiden (undoubtedly in the house of A. S. Matveev), he must have arrived before January 1671. (See Reutenfels 1680, 97: "Quod vèl ex vultu eius, \& adspectu licuit præsagire, cùm illa nobis, innupta adhuc, Moscuæ bis visenda fortè fortunæ obtingeret [...]”.) On pp. 96-98 he gives a lively description of the new tsaritsa's beauty and character. Her marriage to Tsar Aleksej took place on 22 January 1671.

8 If we are to trust the information given in a letter by Count Valerio Zani, sent from Bologna to Antonio Magliabechi and dated 20 June 1674, Rautenfels spent more than two years in Dr. Rosenburg's house in Moscow (Stensen 1952, 42). For details about Dr. J. Coster von Rosenburg see Dumschat 2006, 477-479; 588-590, and Dumschat 2011.

9 According to the tsar's ukaz from 8 March 1672, published in Skazanija 1906, 215, one of Dr. Rosenburg's sons, Gendrik, and a "plemjannik" were allowed to leave Moscow to go to Wilna: "отпуститъ [... А дохтура Иоганава сына Розенборха Гендрика Аа племянника ево Иакова Рутефемева.” The 17th-century meaning of plemjannik was not as specific as the modern meaning; it could also denote a more distant family relationship (see SRJa XI-XVII, 84). Gendrik must be the son who was baptised on 13 June 1653: "Den 13. Junij ist Herr D. Johan Costers Söhnlein getaufft, so genant Johan Heinrich” (Tallinn Municipal Archives, shelf number 31-1-13, fol. 34v; with thanks to Jürgen Beyer, whose transcription we are quoting here). Another son, Christian Friderich, was baptised on 21 June 1654 (ibid., fol. 38v).

10 In October 1667 he wrote a letter from Cracow to his father (Stensen 1952, 41-42). 
On 8 March 1672, Rautenfels and one of the doctor's sons received permission to leave Moscow in order to study at the Jesuit university in Wilna; they must have left Moscow at some point between mid-March and the end of May ${ }^{11} 1672$. Presumably, Rautenfels was somewhat older than Rosenburg's son Heinrich, who was 18 years old; this son converted to Catholicism, entered a monastery, and terminated contact with his parents (Dumschat 2006, 589). Rautenfels did not linger in Wilna, however: after handing the young man over to a Catholic "inspector" there, he continued on to Sweden (Dumschat 2006, 478). ${ }^{12}$ In November 1673 he enrolled at the University of Bologna, where he spent about a year. From November 1674 we can trace him in Rome, where he was in contact with the famous Jesuit scholar Athanasius Kircher $^{13}$ (Proehl 1962, 457).

During his years in Italy Rautenfels wrote a book about Muscovy. The manuscript was finished in Florence, at the court of Grand Duke Cosimo III of Tuscany (r. 1670-1723), apparently after January 1676 (because he mentions the death of Tsar Aleksej Michajlovič and describes the funeral; Reutenfels 1680, 85-86). A few years later, a German scholar found Rautenfels' text in Cosimo's library and, with the permission of the library's director, Antonio Magliabechi, he was allowed to make a copy of it (Reutenfels 1680, fol. a3va4r); this copy was eventually published in Padua as De Rebus Moschoviticis ad Serenissimum Magnum Hetruriae Ducem Cosmum Tertium (1680; neither of the two manuscripts - Rautenfels' original or the scholar's copy - seems

11 According to Cholodov (2000, 65), Rautenfels left Moscow after 30 May 1672, the date Peter was born. His conclusion is based on the Russian translation of Rautenfels, which says that Peter was born 'shortly before our departure' ("незадолго но нашего отъезда"). However, the Latin version has: "In secundo matrimonio, sub nostrum ex urbe Moscua discessum, Regina Natalia filium principem, Petrum nomine, felici in lucem dedit partu [...]" (Reutenfels 1680, 98). The timeframe expressed in this phrase is best translated as 'around the time of our departure', which means that he could have left a couple of days or weeks before the birth of the prince, on 30 May. Since Rautenfels does not mention a second "ballet" performance, which was described as taking place 'last week' in a document dated 28 May (see Jensen and Maier forthcoming), we assume that he was not in Moscow at that time; we suggest that Rautenfels left Moscow, at the latest, before this presentation, thus at some point around 19 May.

12 According to a letter kept at the Biblioteca Nazionale in Florence (referred to - but not published - in Stensen 1952, 42), Rautenfels visited Riga, Uppsala, Copenhagen, and Hamburg; it would be most logical to assume that he visited all these places before he came to Italy - between his stay in Wilna and his arrival in Bologna.

13 About this great scholar's life see Dünnhaupt (1991, 2326); for a bibliography of his work ibid., 2328-2349. 
to have survived). In Rome, Rautenfels converted to Catholicism (in 1675, according to Tering, forthcoming). Later, in November 1677, he left Italy, following the Danish scientist and bishop Niels Stensen (1638-1686) to Hanover. Stensen sent Rautenfels back to Florence in 1681, but he died during this return journey, in September 1681 (his last letter - to Antonio Magliabechi - is dated 23 July 1681; Stensen 1952, 41-42).

In the printed book from 1680 the author's name is given as Reutenfels (fol. a3v) - possibly a typographical error, since this form does not appear in any of the known historical documents. In the introduction to the German version of the book, Das Grosse und mächtige Reich Moscovien [...], printed in Nuremberg in 1687 and based on the Padua edition of $1680,{ }^{14}$ the form "Reutenfels" was repeated, thus enshrining this spelling in library catalogues throughout the world. We use the original spelling of his name (except when reproducing the orthography in bibliographical references).

The details of Rautenfels' life are important because his description of a staged performance (or performances) in Moscow is a fundamental starting point for studies of Russian theatre. Scholars have questioned his credibility (e.g., Cholodov 1983, 153-158), and our study should help to resolve this issue. As we will show, he was not only an eyewitness to some kind of presentation in Moscow (as has been suggested before), but he was almost certainly one of the active participants! However, Rautenfels did not appear in the Esther presentation in October 1672 (he had left Moscow before this performance took place), but rather in a completely separate entertainment, a "ballet" presented to the tsar, his family, and some influential boyars half a year earlier, in February.

14 The discussion in Cholodov $(1983,158)$ on the origins of Rautenfels' work is unclear. He gives the name Johann Christoph Lochner as the scholar who discovered Rautenfels' manuscript text in Florence in Cosimo's library and published it in the Latin version of 1680; there is no source for this identification. Johann Christoph Lochner (1653-1730) was the Nuremberg publisher who issued the German version of Rautenfels' text in 1687; we have so far discovered no evidence linking him with the earlier publication or the discovery of the manuscript. The relationship between the Latin and the German publications is complex and beyond the scope of the present article. However, it is worthwhile to note that the German publication does not seem to be an exact translation of the Latin (indeed, the preface mentions using "other authors" - not, however, specified). Rautenfels almost certainly wrote his original (lost) version for Cosimo in Latin. The Latin text was translated into Russian in Skazanija (1905; 1906), which was reprinted in Skazanija 1997. A facsimile edition of the Latin text is in Reutenfels 2003. 
We quote in extenso from Rautenfels' chapter IX, “De Recreationibus Zari” (Reutenfels 1680, 104-107), not only because this passage has been so important (and very much misunderstood) in studies of early Russian theatre, but also because our new translation from the Latin original (see the appendix) avoids some of the problems of the often quoted and somewhat loose translation into Russian (Skazanija 1905, 88-89). ${ }^{15}$

In the first sentence of the passage about the theatre, Rautenfels mentions the Esther play: ${ }^{16}$

Moreover, in recent years he [Aleksej Michajlovič] allowed some foreigners who live in Moscow to present for himself a dancing scene, and also the story of Ahasverus and Esther, described in a comical way.

This statement about the Esther play - performed on 17 October 1672, after Rautenfels had left Moscow - certainly conforms to theatre history as it is known from Russian sources, and the text of the play he mentions is preserved primarily in two manuscript copies. ${ }^{17}$ However, this is the only sentence in this passage that relates to the Esther play, which Rautenfels knew only from hearsay. Already in this first sentence he mentions "a dancing scene", and although the Latin text would not exclude the interpretation that this scene and the Esther play formed a combined presentation (that is, that the play contained some dancing), other details of the description make it clear that this was not the case. As we now can prove, the Esther play is just mentioned in passing, only once in this first sentence, and the rest of Rautenfels' report is about a "dancing scene" that took place much earlier. Rautenfels continues:

Since he had been hearing through reports from time to time that different plays, dances, and other amusements are often given for European princes, in order to pass the time and disperse boredom, he suddenly ordered that

15 For instance, the translator misread the word considens ('sitting') as confidens. (See also our discussion about "die [...] Bacchanalium ludorum penultimo" below.) Part of this passage, based on the Russian translation, was published in English in Findeizen 2008:1, 255, and the entire passage, also based on the Russian translation, is in Jensen 2009, 164-165.

16 We use square brackets for editorial notes in this and in all following sources, and also for the insertion of original terminology from our sources (in italics).

17 The Russian and German texts are in Mazon and Cocron 1954 (this source lacks act 2, which is published in Günther 1968) and in Pervye p'esy 1972; the Russian text is in Artakserksovo dejstvo 1957. There is an English translation in Louria 1968. 


\section{Claudia Jensen, Ingrid Maier}

an example of such a production in the form of some sort of French ballet [tripudium] should take place. Thus, in view of the shortage of time, in one week with all possible haste everything necessary for the staging was prepared. Whereas this performance would not have been able to be seen without anticipated apologies in any other place but Moscow, to the Russians it appeared unique and artistic since the new kinds of costumes, the unfamiliar appearance of a theatre stage, even the marvelous idea that it was something foreign, and also the strains of the music, never heard before, easily awoke their admiration. At first, it is true, the tsar did not want musical instruments to be used, as being something new and rather pagan, but when the dancers argued that they could not present a decent dance without music, just as it is impossible to dance without legs, he - a little unwillingly - left everything to their discretion. The tsar watched the entire presentation sitting in an armchair in front of the stage; the tsaritsa, however, and the royal children watched through a lattice, or rather through slits, from a wooden construction that had been built opposite the scene, separate from the audience. The aristocrats (everybody else had been ordered to stay away) were standing on the stage.

The passage about the "aristocrats" (that is, the boyars) who were standing on the stage has been widely discussed, but always in connection with the Esther play in October. It is clear, however, that Rautenfels is talking about a different presentation, one that, as we know from other sources, lasted for "only" three hours. As Rautenfels says, this presentation was put together very hastily, in just a week (unlike the later plays, which required long rehearsal periods), and the stage or performance space was certainly much simpler. Under these circumstances, the small number of spectators might indeed have been standing around the performance area, with the tsar and his family seated comfortably.

Rautenfels' next passage contains a remark that has been mystifying historians for many decades:

The celebratory verses to the tsar, declaimed by Orpheus, before he began to dance between two moving pyramids, were rude and inelegant; however, I find it necessary to quote them here, out of respect to the most honoured Aleksej. 
Scholars have focused on this statement, asking not only why the character Orpheus might have been dancing between two pyramids, but also if this took place during the Esther play. The most influential attempt at providing some sort of context for this remark was by the music historian Nikolaj Findejzen (1928:1, 321-323), who proposed that the Orpheus reference was to a Moscow performance of a play with dance and music (by Heinrich Schütz, no less) that had originally been written for a royal wedding in Dresden in $1638 .{ }^{18}$ In some ways, this notion made sense, as the actors in Moscow were largely from German-speaking (and even Saxon) lands and would probably have been familiar with at least some German performance traditions and possibly even specific performances, such as this wedding event. After this, scholars cast about, trying to place this hypothesized German work in a variety of possible chronological slots. ${ }^{19}$ No one, however, was particularly persuasive, and the mystery of the dancing Orpheus remained. As we will see, Rautenfels referred not to an evening featuring dance, but rather described a mixed bag of staged comic performances, along the lines of the "English comedians" so popular throughout the German-speaking territories on the Continent beginning in the late 16th century, who performed a series of vaudeville-like skits, with identifiable comic characters, music, dancing, and much physical comedy. ${ }^{20}$ One of the many characters in this Moscow performance was Orpheus, who read a poem to honour the tsar, and one of the impressive stage effects was the appearance of two pyramid-shaped mountains.

It is not clear how Rautenfels was able to reproduce this poem - either he brought a text with him when he left Moscow or he reproduced these lines from memory. However, it is also possible that he himself was the author of

18 Findejzen cites Koch 1911. The ballet was written for the wedding of Elector Johann Georg of Saxony and Princess Magdalena Sybilla of Brandenburg. Only August Buchner's libretto survives; see Hoffmann von Fallersleben 1855 and "Schütz, Heinrich" by Joshua Rivkin and Eva Linfield, Grove Music Online (www.oxfordmusiconline.com, accessed 13 March 2013). As will become evident from our investigation, this work is unrelated to the Moscow performance.

19 For instance, E. G. Cholodov (1983, 157; 2000, 63-65), who states that the Orpheus presentation marks the beginnings of Russian ballet, suggests that the "Orpheus ballet" took place during Shrovetide 1675. This scholar also notes that the historian I. E. Zabelin had suggested a performance date of 17 February 1672, which, as we shall see, is almost the correct date. See below for additional discussion of the range of dates suggested by Cholodov.

20 Descriptions of the traveling English players on the Continent are in, e.g., Limon 1985; for important connections to the English performance traditions, see below. 
these verses, perhaps in connection with his proposed job as a private tutor to the Rosenburg sons. ${ }^{21}$ At any rate, the "rude and inelegant" verses (in our own "rude and inelegant" translation) are as follows:

Is today the day

Is it, at last, here;

When we bring the Tsar joy

And before Him appear?

We submit to You

Bowing low, humbly;

And we kiss Your feet

Not one time, but three.

Your realm is so great

Your rule is so wise;

Yet greater still

Does your glory rise.

Through bravery and wit

You'll bring us release;

From the long night of struggle

To golden days of peace.

Your righteous rule,

Through its heavenly shine,
Along with Your mercy

Makes Your temper divine.

Your greatness so perfect

So heav'nly its sway,

That in this, Your time,

All bow low and give way.

You, bright Russe sun,

With the moon and stars too,

Live long in great bliss

With no sadness to rue.

Rule long, friend of heaven

Discontent You'll contain;

You, so close to heaven,

Long will You reign.

So strike up my strings,

Let them sound out so strong,

And you, pyramid mountain,

Leap in joy with my song.

At the very end of the chapter about the tsar's leisure activities, Rautenfels writes:

21 Cholodov (1983, 157-158) suggests that Rautenfels and Rinhuber might have met in Florence in 1678, and that they might have exchanged information, including the poem. This appears unlikely because, as noted above, Rautenfels had left Italy the previous year. Although it is not impossible that they met at some point during their extensive travels (on Rinhuber's whereabouts, see Brikner 1884), we have so far discovered no evidence to support this. 
On that same day - namely the penultimate day of Shrovetide - the tsar also organized a hunt on the Moscow River, which was frozen over. There large English dogs and other kinds of dogs fought with some white Samoyed bears, a spectacle that was all the more entertaining, the more they stumbled on the slippery ice. In the evening, however, the tsar went to see fireworks on the same ice.

In this final fragment we get an approximate date for the presentation Rautenfels had been describing in such detail: "the penultimate day of Shrovetide". In the Russian translation a concrete day of the week was given instead: "B этот же Аень, субботу на масленице [...]" ('on this same day, Saturday in Shrovetide'; Skazanija 1905, 89). Theoretically, as E. G. Cholodov (1983, 156) notes, this could have been 17 February 1672, 8 February 1673, 28 February 1674, or 28 February 1675; he suggested 1675 as the most likely choice (see footnote 19). As we now know from other sources, the correct date for the performance is 16 February 1672, which was a Friday, not a Saturday (apparently Rautenfels regarded Saturday as the last day of the week, whereas the last day of the week according to his Russian translator was Sunday). We also understand why everything had to be prepared in haste: it would, of course, have been impossible to arrange any amusing presentation during the long fast before Easter.

\section{Source Two: A German Newspaper Article, March 1672}

Although 20th-century theatre specialists have struggled to understand exactly what kind of presentation Rautenfels was talking about, many 17thcentury diplomats, bureaucrats, and even hundreds (and very likely more) of ordinary readers of printed newspapers in the West would not have been puzzled by his description at all. Our focus here is an article published in the Hamburg newspaper Nordischer Mercurius, founded in 1664 by Georg Greflinger, the first German professional journalist, who was also a famous poet, novelist, and translator. ${ }^{22}$ During the period in question, the small-format

22 It was perhaps due to Greflinger's intellectual capabilities that this newspaper was far ahead of its time (for instance, the individual articles were grouped together according to geographical regions, not just printed in the order in which they happened to land on the publisher's desk). On G. Greflinger see Dünnhaupt 1991, 1680; for a detailed bibliography of his work ibid., 1681-1751. On his Nordischer Mercurius see Bogel and Blühm $1971,180-185$. 
newspaper - four leaves printed in $8^{\circ}$ - appeared twice weekly (beginning in June 1672 there were four weekly issues). In the last of the nine ordinary issues printed in March 1672, there appeared a substantial article under the headline "Moßkau vom 23. Februari" (pp. 197-198). ${ }^{23}$ Large parts of this correspondence from Moscow - in fact, this very passage about the theatre - were quoted some decades ago in an article by the press historian Martin Welke (1985, 281-282; see also Dumschat 2006, 411), but unfortunately this material was not noted by scholars of the Russian theatre. We quote this source, too, in its entirety, because this is the earliest securely and precisely dated source relating to the origins of theatre in Muscovy, and because it provides a sense of the kind of news that was considered to be of interest to Western readers. We have divided our translation into three sections, as follows:

\section{Moscow, 23 February.}

Not much is going on here in public life. The Polish gentlemen ambassadors are diminishing their suite considerably. Recently, another 30 people, including a dead Pole, have left, and it is said that tomorrow 40 will be leaving, mostly noblemen, so that only three of the most distinguished persons will still be here. However, nothing special about their activity is being assumed. His Tsarish Majesty has been amusing himself before Lent with bearbaiting, fireworks, and similar things. On the 16th of this month, 12 Germans presented a ballet for His Tsarish Majesty in the palace of the tsar's father-in-law, Ilia Danielowiz. It consisted of 4 Romans, 4 wild men, 2 drunk peasants, and 2 cutpurses, to whom was added an amusing Pickleherring. The scene [Theatrum] was very beautiful, and His Tsarish Majesty was sitting quite close to it with four of his princes and most important ministers.

We notice immediately that there is a good deal of overlap between this newspaper article and Rautenfels' book chapter; for instance, the bearbaiting and the fireworks that took place on the same day are mentioned in both descriptions. Although this report does not mention either Orpheus or the

23 The pagination of the Nordischer Mercurius during this period was continuous for each year. The individual issues had no title or printing date on them; the title was printed on the title page for each year. We used the original issue kept at Uppsala University Library (shelf mark: Hist. tidskr.). Copies of all preserved German-language newspapers from the 17 th century can be found at the research institute Deutsche Presseforschung in Bremen. 
pyramids, it does provide a clear picture of comic Western popular theatre, involving different characters (Romans, wild men, drunk peasants, etc.), music, and general mayhem - the latter provided by the stock comic character Pickleherring, explicitly named in the report. ${ }^{24} \mathrm{We}$ also get an exact date: 16 February. A performance on this date was a natural fit, for this was the period of maslenica, with its associations of license and entertainment, masking and role-playing (see, e.g., Lichačev et al. 1984). This, in turn, corresponds to the description by Rautenfels, who also mentions that the "dancing scene" took place "on the penultimate day of Shrovetide".

We now learn that 12 performers took part, and that the spectacle took place in the residence of the late Il'ja Danilovič Miloslavskij (1594-1668), in the Kremlin, and not in a specially constructed theatre building. ${ }^{25}$ Furthermore, the article provides a good estimate of the number of boyars who attended. The phrase "four of his princes and most important ministers" must be interpreted as indicating that there was a total of four people. At the time, there were two surviving princes, Fedor and Ivan (who was not quite six years old); the organizer of the production, Matveev, must have been one of the two ministers. The article also offers a charmingly intimate portrait of the tsaritsa and other female members of the royal entourage peering from behind a curtain ${ }^{26}$ - the description is, indeed, almost theatrical in its depiction of the assembled audience:

The tsaritsa or empress was sitting with her state ladies behind a scarlet curtain, which afforded a glimpse of their beauty and allowed them to see the ballet clearly. They were shining like brilliant stars through small clouds, and since this ballet was the first that has ever been seen in Moscow, it provoked a great deal of interest. The tsar together with his 4 princes and most important ministers as well as the tsaritsa with her ladies

24 For more context about this Western character and his influence on the Russian court theatre see Jensen and Maier (forthcoming).

25 This explains the references in Russian archival documents from May 1672 and January 1673 relating to theatrical supplies (fabrics and carpets) in Miloslavskij's residence (Bogojavlenskij 1914, 1 and 31).

26 Other authors noted such fabric enclosures for the royal women; see, e.g., Paul of Aleppo 1834, 223 and Kotošichin 1980, 32. In February 1672, there were six princesses (who ranged in age from around 10 to around 22 years old); all three of Aleksej's sisters - Irina, Anna, and Tat'jana - were still alive, and there may have been other female attendants as well. 


\section{Claudia Jensen, Ingrid Maier}

were so pleased with it that they often almost shook with laughter, and after the end they asked for another presentation on the following day. However, the next morning the patriarch died, and therefore it was asked to postpone it until Easter. The participants were presented with wine and mead, which is considered to be a great honour here. There was also hope of getting some presents from the tsar, especially sable furs, and there is still no reason to question this [future] grace.

The final fragment of the article indicates that the unfamiliar instrumental music and the singing aroused particular interest:

The music consisted of 2 violins, 1 viola da gamba, and 2 singing voices, which [altogether], as could be noted, amused the ladies very much, as being an unusual [kind of] music. This is being written to show that something that is very common for our German people is seen as something new in these parts.

The article thus concludes by stressing the backwardness of the easilyamused Russian audience (and, consequently, the advanced tastes of the newspaper's readership), something that also has a parallel in Rautenfels' report ("this performance would not have been able to be seen without anticipated apologies in any other place but Moscow"). Unfortunately, we cannot tell how many changes the newspaper's editor, Georg Greflinger, might have made to the report he received. Greflinger's sources would have been handwritten newsletters (in this case, one compiled in Moscow), which he would then edit for his newspaper. No such source material has been preserved, but given the fact that both Rautenfels and our next source emphasise that such a presentation was something very unusual in Moscow, it seems reasonable to conclude that this sentence was not an editorial addition, but belongs in some form to the original (anonymous) letter that was sent from Moscow. We have so far uncovered no other German-language newspaper article describing a theatrical presentation in Muscovy (or, for that matter, in any other country), ${ }^{27}$ although it is possible that this article also appeared in

27 This conclusion is based on the subject index at the Deutsche Presseforschung in Bremen. Although this index (in the form of a card catalogue) might not be complete, it is nevertheless clear that it was very unusual for German or Dutch newspapers in this period to discuss any sort of theatrical presentation at all (either in Muscovy or in the West). We know of only one more article in a German-language newspaper issued between 1613 
the Copenhagen newspaper Extraordinaires Relationes, which - as has been shown for the year 1669 - was composed of material that had been printed before in one of the three Hamburg newspapers, among which was the Nordischer Mercurius (Ries 1977). ${ }^{28}$

\section{Source Three: A Diplomatic Report from Moscow to Bengt Horn}

Our next two sources are reports, sent to different Swedish government officials (as enclosures to letters). The first of these sources is an enclosure to a short letter from Narva (signed by S. G. Helmfelt, the governor-general of Ingria), dated 27 February 1672, apparently sent to Bengt Horn (16231678), governor-general of Estonia since 1672. We quote the enclosure in full:

Moscow, February 20. Anno 1672.

On the 17 th of this month, around 8 o'clock in the morning, the patriarch here departed this world, at the age of approximately 84 years. Presumably, toward Easter another person will be chosen in his place. Last Friday His Tsarish Majesty, his spouse, and the whole family watched a ballet, arranged by 12 persons, mostly foreign merchants. Its author was Dr. Rosenburg's son, who came to this country recently, and His Tsarish Majesty liked it very much. He was sitting very close and was visible, whereas the women were hidden behind a red curtain, however in such a way that their faces were perfectly visible. When the ballet was finished, His Tsarish Majesty's thanks were expressed and it was said at the same time that they [the performers] should come back on the next day toward the evening. However, since the patriarch passed away the following day, this did not come true. One is astonished that His Tsarish Majesty, together with his whole family, watched something like this, since previously it had never been permitted to watch anything similar. His Tsarish Majesty and the women laughed several times so that one could hear it, especially at Pickleherring's antics and faces. During the whole presentation -

and 1689 that mentions the Russian theatre; cf. Welke 1976, 209-210, note 468. (Martin Welke has studied all reports about Russia in German printed newspapers from this time range that were in Bremen in the early 1970s, altogether 9478 reports about Muscovy in 34670 newspaper issues; ibid., 165.)

28 Unfortunately, no issues printed in Copenhagen during the relevant period have survived (Bogel and Blühm 1971, 198). 
which lasted for more than three hours - nothing was said, except that Dr. Rosenburg's son at the beginning and at the end directed a speech in German to His Tsarish Majesty. The costumes cost about 200 roubles. The scene was covered with carpets and green fabric. Last week the Polish ambassadors were received again, but nothing was decided. Their courier, who was sent to their king with some conditions postulated by the people here, has not yet returned. Meanwhile many noblemen among them [the ambassadors] are going back to Poland. Some days ago a nobleman, whose name is Stabrofskij and who has deceased here, was sent back with 30 persons, and today more than 40 persons - mostly noblemen returned, so that only the leaders and a few [other] people are still staying here, waiting for further instructions. This week the Russians stay at home, cleaning and preparing themselves for their fasting period.

This document thus verifies the date for the presentation given in the newspaper article: the "ballet" was given "last Friday", which, in the context of a report written on 20 February, would be 16 February. Indeed, the next day, 17 February 1672, is the date on which Patriarch Ioasaf II died. The information about the Polish ambassadors overlaps largely with the version in the Nordischer Mercurius, but this diplomatic report is more detailed. For instance, the deceased Polish ambassador is now identified: Stabrofskij (apparently, Stabrowski).

The number of "actors" listed here is the same as in the newspaper article, but they are described more fully as "mostly foreign merchants" (as we will see in the next section, about half of them were merchants). We also learn that the "author" of the production was one of Dr. Rosenburg's sons. (Presumably, this was Bernhard, the oldest of the doctor's ever-increasing number of sons.) The presentation took more than three hours, a relevant figure because, as Rautenfels said, the (very few) aristocrats who were invited stood throughout (see also Cholodov 2000, 55-60).

The author also provides specific details about the performance. There was no spoken dialogue, apart from the two "speeches" declaimed by their author, the young Rosenburg (undoubtedly, one of these two "speeches" is the poem later quoted by Rautenfels) - the production thus relied upon miming and physical activity, in addition to the musical performances. He also notes the 
lavish costumes, ${ }^{29}$ as well as the decorations. As in the newspaper account, we are told that the tsar liked the presentation, Pickleherring especially, very much; he even asked for a continuation the next day, that is, on Saturday. However, neither Orpheus nor the pyramids appear in this report - this last mystery will be resolved only in our next document.

\section{Source Four: An Eyewitness Report from the Stage Itself}

The most detailed account of the February event that we know about is a long, undated report with the title "Extract Schreiben von Muscow", also kept in the Swedish National Archives. ${ }^{30}$ Apparently, this is another enclosure that was sent to the Swedish government by S. G. Helmfelt from Narva, together with his own letter, addressed to the king of Sweden. ${ }^{31}$ We have not been able to identify the author. The language in this document indicates that he comes from the northern part of the German-speaking territory, and that his mother tongue is a Low German dialect. Indeed, he tries to write in the literary German language, but he fails frequently and in a way that is typical for speakers of Low German. ${ }^{32}$ However, there are several indications that

29 The figure of 200 roubles, cited in the report, is quite high. As a comparison, the foreign instrumentalists who were later hired to perform for the tsar's theatre were paid 6-8 roubles per month (Bogojavlenskij 1914, 17-18).

30 RA, Livonica II, vol. 180 (containing letters by S. G. Helmfelt to the Swedish king and attachments forwarded by him from the period 1671-1673). A note in pencil written by an archivist on the first page of the document, "Bilagor till br[ev] av 29 dec. 1671" ('enclosures to letter from 29 Dec. 1671'), is apparently wrong. Another letter by Helmfelt from Narva, dated 29 February 1672 - written in Swedish, which is quite unusual as most of his letters are written in German - contains an enclosure with two reports from Moscow (dated February 6 and 13, respectively); the latter mentions the ballet as a future event: "[...] So wird auch ein ballet, auf befehl von Ertemon Sergiofvits, von einigen außlender diese Woche auf Ihre Zaar Maÿ:tt unkosten, verfertiget, welche I. Z. M:tt selber anzuschauen belieben werde" ('... At the order of Ertemon Sergiofvits [i.e., A. S. Matveev] and at the expense of His Tsarish Majesty a ballet is being produced this week by some foreigners, which His Tsarish Majesty himself is going to watch').

31 Charles XI (1655-1697) inherited the royal crown in 1660, when his father died; at the time, he was not yet five years old. His coronation took place in December 1672, when he attained his majority.

32 See Beyer 2012 for many examples of similar language in Lübeck inscriptions and archival records. Because of this very peculiar language, this source was quite difficult to transcribe, and a few words and phrases remain unclear. We are very grateful to Jürgen Beyer, who corrected our transcription, pointed out the Low German elements in it, and improved our translation into English. Any remaining errors are ours. 
this is a copy, not the original report. For instance, the title "Extract" points to the fact that a copyist has selected material for inclusion, and the document includes a wide range of name forms, which might be explained as copying errors (see examples in footnote 45).

This report describes the elements of what it - like the Nordischer Mercurius article - labels a "ballet", with vignettes involving named characters as well as generic ones; comic routines featuring the antics of Pickleherring; and musical numbers. This report is quite long (three handwritten pages); we quote it below in full, divided into four sections:

Summary Letter from Moscow

Nothing particular has happened since Your [des Herrn] departure, because [i.e., as a result of this lull] His Tsarish Majesty let himself be entertained during this period of fasting with all kinds of amusing things, namely bearbaiting, fireworks, and finally a big ballet, which the 12 of us presented at the castle, in the tsar's mother-in-law's, Ilian Danilowitz', residence, in such a way that, without boasting, His Tsarish Majesty, his wife, and also the princesses and the honourable State Counselors were very pleased with it. His Tsarish Majesty was sitting right in front of the stage [Theatrum]. The same is true for the aforementioned Royal Women, who, however, were screened off with red drapery. However, soon they cut up big holes through which they could look. The tsar was in a very merry humour. The stage was covered with green cloth, and also with gilded leather; in its centre was a marvelous big mirror. The floor was covered with very beautiful carpets. To this purpose we had beautiful clothes made of nice Asian [Aseaschen $]^{33}$ and red cotton [Kindiaken] and also taffeta [or satin; Taften] fabric, which His Majesty had ordered to be purchased in cash from kiosks and had sewn up by 25 tailors in the Roman manner.

The wording "des Herrn" in the first sentence suggests that the recipient had recently departed from Moscow. Therefore it is not likely that the report was originally addressed to the governor-general in Narva, S. G. Helmfelt, for whom no trips to Moscow are known, although it was certainly Helmfelt who had a copy made for the Swedish government in Stockholm (and pos-

33 This is one of the adjectives used to describe the costumes prepared for the performance. The association may be through the Russian word aziatka, a type of traditional Russian women's dress; literally it should mean 'Asian'. 
sibly for the governors in Reval and Riga). One person who was in Moscow in 1671 and 1672-1674, as an envoy extraordinary (Schlegel and Klingspor 1875,59 ), is Adolph Ebers (after being ennobled in 1666: Eberschildt/Ebersköld); he was Johan de Rodes' successor as permanent Swedish resident in Moscow in 1662-1665 and 1667-1669 (Hildebrand 1945, 778). It appears from Rautenfels' book that he knew Eberschildt personally - in fact, he even calls him a "relative" 34 (of course, the author may have been exaggerating their relationship somewhat). Moreover, when Eberschildt arrived in Moscow, on 13 November 1671 , he was sick, and the tsar then sent his personal physician - who was none other than Dr. Coster von Rosenburg, Rautenfels' landlord to treat him. ${ }^{35}$ All this makes it likely that Eberschildt and Rautenfels had met in Moscow. Furthermore, Eberschildt departed from Moscow on 27 January $1672,{ }^{36}$ that is, about three weeks before the "ballet". Such a detailed description of the performance would make sense only for a person like Eberschildt, who would have been familiar with most of the participants, and this would accurately reflect the wording in the introduction ("since your departure"). However, the recipient apparently considered this report to be of general interest as well, and forwarded it to Helmfelt, so that one copy, our source No 4 (the "Extract"), finally ended up in Stockholm. ${ }^{37}$

From this introductory passage we learn that the "ballet" - the same term as in our previous sources - took place in the house of the tsar's mother-inlaw (!), "Ilian Danilowitz". There is no doubt that the author is talking about Il'ja Danilovič Miloslavskij (the father of Tsar Aleksej's first wife), so this information coincides with the article in the Nordischer Mercurius, where the

34 "Vndè cum Anno 1672. Nobiliss[imus] Adolphus Everschild, cognatus noster, à Svecorum Rege nuntius, in Moschoviam missus [...]” (Reutenfels 1680, 131; 'When the most honoured Adolph Everschild, our relative, was sent as an envoy to Muscovy by the Swedish King, in 1672').

35 RA, Livonica II, vol. 180 (enclosure from Moscow, 21 November 1671): "Doctor Rosenburg ist von Ihrer Zaar. Mtt. ihn zu besuchen vergönnet worden, darmit er desto schleuniger wiederum zu seiner Gesundheit gelangen möge.” Dr. Coster von Rosenburg had previously been personal physician to King Charles X of Sweden (and after his death, in 1660, to his widow, at least until March 1667; see Dumschat 2011,112), so it is most likely that Eberschildt had met the doctor earlier, in Sweden.

36 RA, Livonica II, vol. 180 (enclosure from Moscow, 30 January 1672).

37 The original addressee might also have been someone else in Eberschildt's suite, not necessarily Eberschildt himself. At least, because we know that Helmfelt forwarded this "Extract" to Stockholm from his post in Narva, the addressee - whether Eberschildt himself or someone from his retinue - would have traveled directly from Moscow to Narva. 
residence of the tsar's father-in-law is also mentioned. (Miloslavskij died in 1668 , and his house was acquired by the state the following year. $\left.{ }^{38}\right)$ Also the information about the royal ladies, who were screened off from the rest of the public, is repeated here, but with a new element: they cut big holes in the red drapery in order to provide a better view of the performance. The description of the performing space also corresponds to our previous sources, although here, too, we learn some new details, such as the big mirror and the costumes that had been sewn by 25 tailors "in the Roman manner", from materials purchased locally at the order of the tsar. The performers thus appeared before the royal family in appropriately elaborate costumes and in a correspondingly elaborate setting.

In contrast to our previous sources, where the writers were content to note only that there were twelve actors, "mostly foreign merchants", this author gives us a whole list of names and even the roles they played (with a total number slightly surpassing the twelve participants specified in the sources cited above):

In this ballet were the following participants, namely Doctor Rosenborg's two sons, and also his house teacher [Studiosus], Mons. Trautenberg; Mr. Butinant's house teacher; both Misters Siwerts - the elder brother was inventor and author, along with Mons. Rosenburg, who personally was acting in the role of four different characters, namely as Mercurius, Orpheus, a Moor, and, in the fourth place, as a wild man. Mons. Christo[ffr] Roden was a hunter in green morocco [leather] clothes, along with three other persons: Räutenberg and Hasenkrach - who was also a skillful Pickleherring, in

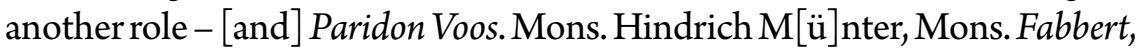
and also the embassy's honourable former stable master were drumming on stage while I along with Mons. Münter were playing the roles of two wild men, and afterwards of two foolish ${ }^{39}$ peasants. You should have seen

If his wife was still alive, it might have made sense to mention the tsar's "mother-inlaw" (the birth and death dates for Ekaterina Fedorovna Miloslavskaja - Il'ja Miloslavskij's wife - do not seem to be known); it is also possible that our author thought Ilian Danilowitz was a woman's name. On the Miloslavskij residence, later called the "Potešnyj dvorec" because of its association with these and the later theatrical productions, see http://dic. academic.ru/dic.nsf/moscow/2514/Потешный (accessed 2 May 2013). The building still exists.

39 One of our previous sources has "drunk" peasants, but this author clearly writes drumbene, not drunckene. The exact meaning of this word is unclear; cf., however, Low German 
the curious jumps in the air, as can be attested some time in the future by Mr. Butenandt, to whom we gave a pass $[\mathrm{Axal}]{ }^{40}$ pro forma, so that he, too, was able to see it - otherwise, it was guarded, so that nobody could come in, except the great boyars, such as Arctemon Czergowitz Trokunow and similar persons, who were very eager to see our presentation [Theatrum].

Some of the performers are easy enough to identify more or less exactly, for instance the two sons, who are probably Dr. Coster von Rosenburg's eldest son, Bernhard, and a younger son; other performers were from the resident foreign merchants (most of whom were from Hamburg), including the brothers Peter and Johann Sievers, Heinrich Münter, Paridom Voss, and Ägidius Tabert (or Tabbert, i.e., the "Mons. Fabbert" mentioned above). ${ }^{41}$ We also see that the author himself was one of the participants: he had two roles (both along with Münter), that is, as a wild man and a foolish peasant. The most important performers were one of Rosenburg's sons, who had four roles (Mercurius, Orpheus, a Moor, a wild man) and is also mentioned as one of the authors of the entire presentation, and Hasenkrach/Hasenbruch, ${ }^{42}$ who played the Pickleherring role (along with a minor role as one of three hunters). Most of the performers seem to be "Germans" (including immigrants from the Netherlands; see footnote 42), some of them apparently in Swedish service (for instance, the former stable master and the author himself, with his peculiar language, influenced by Low German).

Drümpel 'rube, muddler, fool'. We think that the most likely explanation of drumbene is a copying error, druncken $>$ drumben.

40 We could not find this word in any dictionary, but the meaning could be something like an extraordinary authorisation or permission to get in (accès). Any such entrance pass would normally have been provided by Matveev, so the statement that "we gave an Axal [to Butenant] pro forma" suggests that the participants may have circumvented the authorities and allowed him access on their own. Axal could also refer to an object, something the merchant was given in order to blend in with the performers so that he would appear to be a supernumerary or an assistant and thus would be allowed access.

41 We are very grateful to Anke Martens, who provided us with many unpublished details about these merchants (e-mail 14 May 2013). We will discuss these participants in more detail in Jensen and Maier forthcoming

42 On Dietrich/Di(e)rck Hasenkroegh see Martens 1999, 8, 21-22; Amburger 1968, 31. According to Martens $(1999,12)$, almost all of the Hamburg merchant families in Moscow had originally immigrated from the Netherlands; this might explain the characteristic Dutch spelling Hasenkroeg( $h$ ), and also the German and Dutch forms of the Christian name (Dietrich/Dirck). 
Although the merchants who participated in the performance were adults, some of the performers were apparently fairly young, around age 20 and even younger, e.g., the Rosenburg sons. The two "house teachers" (studiosi) mentioned here were young men who had studied at some university (or at least at a gymnasium), but who had not yet finished their studies. It is particularly interesting that Dr. Rosenburg's house teacher was one of the participants. In this report, his name appears in the forms Trautenburg/Räutenberg, but we strongly suggest that this participant is, in fact, Jacob Rautenfels, the author of our first source. ${ }^{43}$ We know that Rautenfels was living in the doctor's house, and it makes sense to suppose that he was there in the capacity of tutor for the doctor's smaller children (see also Tering forthcoming); furthermore, Rautenfels gives a detailed description of I. D. Miloslavskij's house in his book, ${ }^{44}$ so he must have been familiar with this venue.

Our writer apparently did not have a written list of the participants, but reconstructed the cast from memory. We believe that this explains the inexact name forms for Rautenfels, although in general, the inconsistencies in spellings were likely related both to difficulties in handwriting and scribal lapses. ${ }^{45}$ The most serious mistake in this respect is the name of the great boyar "Arctemon Czergowitz Trokunow", instead of Artamon Sergeevič Matveev, the head of the tsar's Diplomatic Chancery (there simply was no boyar "A. S. Trokunov"), who was one of the very few boyars who attended. ${ }^{46}$

43 The forms Räutenberg/Trautenburg indeed strongly remind us of Rautenfels, all the more since the words Berg ('mountain') and Fels ('cliff') are semantically connected. Moreover, if Reutenfels was another name form that Rautenfels used, Reuten- and Räuten- would be phonetically identical.

44 "Denique universam hanc molem spatiosissima Zari palatia, veluti coronant: quorum prius lapideum, \& formâ est, \& magnitudine singulari, alteru[m] ligneum, sanitatis tuendæ gratiâ, quod hyeme habitari à Principe solet, \& tertium item lapideum, eleganti artificio structum, quod Elias Danilevicz, Zari hodierni socer, quondam incoluit" (Reutenfels $1680,118)$. Moreover, when Dr. Rosenburg arrived in Moscow, in 1667, Miloslavskij head of the Apothecary Chancery at the time - was his superior (Bogojavlenskij 1946, 14-15).

45 Cf., for instance, the variants Rosenborg/Rosenburg, Butinant/Butenandt, Hasenkrach/ Hasenbruch.

46 This error creates several problems. It is possible that the author was thinking of the Troekurov family. Two members of the family reached the rank of boyar in the 1670 s, but in both cases this was after the performance reported here (Boris Ivanovič in 1673 and Ivan Borisovič in 1677; see Crummey 1983, 191 and 198; Cholodov (2000, 45) thus includes Boris Ivanovič in his listing of possible spectators at the later court theatre). However, it is unlikely that Boris Ivanovič would have been invited to Matveev's specially prepared 
It is clear from this report, too, that the presentation was attended by a very limited public. The well-known merchant Heinrich Butenant ${ }^{47}$ was perhaps the only foreign spectator who did not have an explicit role in the play, but was invited "pro forma", in his capacity as the host of one of the performers (the private tutor, or studiosus, in Butenant's house). This writer does not mention that the boyars were standing on the stage, as did Rautenfels, but judging from this account, it would be reasonable to assume that at most only a couple of "ministers", in addition to Matveev, attended.

Let us return to our author's vivid description:

His Majesty and the above mentioned women liked it so much that they shook with laughter several times, especially the tsar. And they had such great patience that they sat for more than three hours with the greatest pleasure. They also permitted us music, specifically, two violins, one viola da gamba, and flutes, as well as transverse flutes. When it had come to an end, His Tsarish Majesty thanked us all through Mr. Artemon Sergowitz. He also asked us to repeat the presentation the next day, which we accepted, obediently. Yet to our disadvantage - since His Tsarish Majesty had planned to give us an excellent reward - the patriarch died the next day. At Easter, undoubtedly, we will have to give the continuation - probably then we will get our reward. Hereby is attached ${ }^{48}$ the song that was sung

performance, as he was allied with the Miloslavskij family, opponents of Matveev (Crummey 1983, 102). On the other hand, this might simply be the result of a scribal error: the author might have written, for instance, "Arctemon Czergowitz Matweew und Iwan Iwanowitz Troekurow", and the copyist might have written the name and patronymic of the first name, then accidentally jumped to the following name, thus combining them (and garbling the final surname). This, however, still does not explain why "Trokunow" (if he is indeed a member of the Troekurov family) would have been present at Matveev's event. We have not been able to resolve this issue.

47 On the merchant, trade representative, and - later - diplomat Heinrich Butenant, who was from Hamburg, see Martens 2001. H. Butenant (c. 1634-1701) had a long career in Moscow (he came to Russia in his youth and was active through the 1690s) and so would have been a familiar figure to the residents of Moscow's Foreign Quarter. He was also, significantly, already known to Matveev at this time through his trade in luxury goods (our thanks to Anke Martens for this information).

48 We think that this understanding of the German verb ergehen is the most likely one in this context, although the verb had many meanings in Early Modern German and we were not able to document exactly this meaning in any German dictionary. We do not believe that the verb is used to describe the presentation itself, since our author never uses presenttense forms when he is talking about past events. If our interpretation is correct, the "at- 
in a very enjoyable way by Mons. Hinrich Münter in this presentation, accompanied by a viola da gamba. This is indeed something special and extremely new in this place, since nothing similar has been heard before. This happened on the passed 16th [of February].

In contrast to our previous sources, this author provides many details about the musical performances, and we also get the date for the presentation, 16 February, the same date as in most of our other sources (except Rautenfels, who has "the penultimate day of Shrovetide"). The "continuation" (or repetition) of the successful show that was planned, and promised, for the next day had to be postponed until Easter, at least; as we will see, the tsar and his family ultimately had to wait until until around 18-25 May for an encore performance (see Jensen and Maier forthcoming).

The final sentences about the "ballet" (before the report turns to current daily political matters) describe the scenery at the beginning of the presentation. Here, at last, the mystery of Orpheus and the pyramids is solved:

This ballet started with a perspective performance [i.e., one with scenery]: The doctor's son, dressed very beautifully, was sitting on a chair; he saw Mercurius - with wings at his head and feet - standing in front of a mountain, nicely made of branches, and behind the mountain a lighted double red-painted eagle appeared. At that time two pyramid mountains became visible in a very pleasing way. Münter and I stood in front of the door opposite each other with clubs on our shoulders, ready to attack. To sum up, it was really nice and everything went well. His Tsarish Majesty would have liked to keep sitting and watching more, but we did not have anything left to perform. His Tsarish Majesty laughed a lot at Pickleherring and this Heinrich Ballon ${ }^{49}$ (the Pickleherring was played by Hasenbruch, and the other one was barber), and, at the end, at the silhouette play, which was quite successful. Thanks to God that his Majesty and the other spectators liked it so much. As for the Polish ambassadors, they are still here, but their number is diminishing from day to day, [they are] leaving for Poland. A fortnight ago a nobleman named Stabrocosckÿ, who had

tached" song mentioned in this report was not filed with this document. Either it was not forwarded to the Swedish government or it was filed somewhere else in the archive.

49 The meaning here, and in the phrase below, referring to "barber", is unclear; the author may be indicating a character in the performance or a personal name. 
died here, was also sent home with 30 men; three days ago another 40 persons left, also mostly noblemen. Shortly the homar ${ }^{50}$ will follow them with a suite, and only the three principals with some staff will remain, waiting for further information. But right now they have achieved next to nothing of their purpose. They are waiting for their messenger, who was sent from His Tsarish Majesty to their king with some suggestions; one has to wait for his decision. They say that Stoncka Raisen's brother is to be torn into pieces by bears.

Rautenfels had described the "pyramid mountains" as moving (and in the poem, they were instructed to leap); here they are described as sets that appeared by means of lighting effects, but which apparently could be moved on and off the performance space. H. Münter and the writer (the two might have been friends, since they always play such paired roles) play wild men, the type of physical comedy so prevalent in this sort of popular performance. But of course, nothing yielded a greater success than Pickleherring, played by "Hasenbruch". We can only speculate as to what the "silhouette play" (Schatten Werck) was like: perhaps a puppet show given in silhouette, perhaps actors appearing behind some sort of screen.

"The doctor's son" mentioned at the beginning of the quoted fragment was probably Johan Heinrich Rosenburg, who went to Wilna with Rautenfels later that same year, whereas it was probably the doctor's oldest son, Bernhard (Boris), who was described as one of the "authors" and who played four roles, giving a speech to open and close the production. Bernhard might well have "come to this country" recently, since he could have studied abroad. (In April 1673, he was employed as a doctor in the tsar's service, and he died in Moscow in March 1675; see Dumschat 2006, 477 and 588.)

The political information at the end of our report coincides with that in sources 2 and 3, except for the planned "execution” of Stenka Razin's brother. (The rebel Stepan/Stenka Razin had been executed in June of the previous year; his brother, Frol, died in 1676, so these rumours of his impending death were premature.) Apparently, this undated report was written somewhat later than the two dated ones (20 and 23 February, respectively), probably in the first days of March 1672: the forty Polish ambassadors - who had not yet departed from Moscow in the two other reports - have now left, too, and this

We have not found this word in any dictionary. 
happened "three days ago". The name of the deceased ambassador - here as Stabrocoscky (cf. Stabrofskij in source No 3) - seems, as usual, to be garbled.

\section{Source Five: A Small Article Published in a Dutch Periodical Newspaper}

On 9 April 1672 (new style, i.e., 30 March, according to the Julian calendar, used in Moscow at that time), the famous Dutch newspaper Oprechte Haerlemse Courant published a short notice dated Moscow, 1 March. (This was one of the papers that came to Moscow regularly and was translated for the kuranty compilations; ${ }^{51}$ see Maier 2004.) It agrees in all particulars with our earlier reports: the number and nationality of the participants; the performance on the eve of the upcoming Lenten fast; the death of the patriarch; even the ill-fated Polish mission. The only slight variation is in the interpretation of the term "ballet", which here seems to be considered as an evening devoted to dancing rather than the mixed entertainments described in our other sources. The report reads in full as follows:

Moscow, 1 March. On the eve of this fast, 12 Germans amused His Tsarish Majesty with a ballet, which was the first that was seen here. However, when it was to be danced once more the following day, the patriarch died and thus it was postponed. The Polish delegates, who are having poor success here, are losing all their people, who are returning home.

This small article thus provided a second group of Western newspaper readers with information about cultural events taking place in Russia. Moreover, the fact that the Haarlem paper published an article about this presentation makes it likely that there could have been one in the Amsterdam paper, too

51 Unfortunately, this news item is not among the preserved newspaper translations (kuranty) of 1672, nor do we have any other translations from this issue. It would, of course, have been very interesting to see how the tsar might have reacted; he certainly could not have imagined that altogether as many as a thousand or so newspaper readers in Germany and Holland would be informed about this "family entertainment" (and perhaps he would not have approved of this). We also do not know whether the relevant Haarlem issue ever reached Moscow: out of the approximately 156 issues for 1672 that were printed (three per week), only a handful are preserved at the Russian State Archives (RGADA; Maier 2004, 214); they are all from the period October-December. 
(we do not know of any preserved issues for the relevant week). ${ }^{52}$ The date for the "ballet" is not given here, but the date mentioned in the headline - 1 March (according to the Gregorian calendar used in Haarlem at that period) - corresponds to 20 February, the date given in our source 3. This means that the editor most probably simply adjusted the date in the newsletter from Moscow to conform to the calendar used in Holland (and most of the Dutch provinces), which was 10 days ahead of the Julian calendar used in Moscow, Stockholm, and Hamburg. Such adjustments were normal practice. The publisher of the Haarlem paper, Abraham Casteleyn, thus may well have received a version that was quite similar to our source $3 .^{53}$ It is also possible that he received the same version of the report as the Nordischer Mercurius, through a "news agency" (a person who copied newsletters and sent them off to multiple subscribers). In this case, it would not be surprising that Casteleyn reduced the report much more than Greflinger did (according to the editorial maxim that the greater the distance from the event, the shorter the article); indeed, the poet Greflinger might well have added some literary formulations in his paper that were not in the original version.

\section{Authors and Authorship}

Who were the authors of these anonymous reports, and how many were there? Could it be that all of these reports (except Rautenfels', of course) were composed by one and the same author, who sent off different versions to multiple recipients? This seems unlikely because there are no longer phrases that are formulated in the same way in these sources; no repetitions of whole passages (although some of them mention the same facts); and the order of the details is also different in our reports. Had there been only one author, it seems very likely that he would have repeated some of his formulations (see,

52 The National Archives in Kew have an issue printed on the following Saturday, 16 April (SP 119/2, fol. 3); the Amsterdam City Archives (Stadsarchief) have an issue printed on Tuesday, 5 April (sign. W 32). Neither source contains any news from Moscow. RGADA in Moscow has only four issues from 1672 (printed in January, October, and December; Maier 2004, 206). There is no bibliography of preserved newspapers in Dutch for the period after 1650. However, the Royal Library in The Hague is making more and more historical Dutch newspaper issues available online; see http://kranten.kb.nl/ (last accessed $25 \mathrm{March} 2013$ ). 53 The phrase bleef alsoo achter in the Dutch newspaper seems to be a translation of the German phrase blieb es nach, which appears in our source No 3. But this item is too short to make any more qualified guesses about which of our German reports (if any) was translated into Dutch in Haarlem. 
for instance, Welke 1976, comparing reports sent to the Swedish government by Johan de Rodes, Swedish resident in Moscow from $1651^{54}$ to his death in 1655 , and the very similar reports that were published in Hamburg newspapers). It thus seems more likely that we have two or three different authors. If there were only two authors, both would have been in the service of the Swedish Crown, but had German as their mother tongue. If there were three authors, the one who supplied the information to the Hamburg newspaper would not necessarily have been employed by the Swedes. As for our fifth source, the very short article in Dutch, we think it was translated from the German, so we are not seeking an independent Dutch author.

In our search for possible authors, we must first of all consider the performers themselves, since we now know that the performance was attended almost exclusively by the tsar and his family (apart from them, only $\mathrm{H}$. Butenant and a few boyars were mentioned). In other words, only the performers and the spectators (such as Butenant) would have been able to provide the kind of details that are mentioned in several of our sources. Thus, the circle of possible candidates is narrowed considerably: we have only twelve possible authors (in addition to Rautenfels), that is, eleven co-performers and $\mathrm{H}$. Butenant, among the few spectators. The latter is, of course, not very likely as an author of diplomatic reports providing information to official Swedish government representatives, since he was a German merchant of Dutch origin (and who later worked for the Danes), but Butenant, who was from Hamburg, cannot be ruled out as a possible author of the report sent to the Hamburg newspaper.

The author(s) of the two diplomatic reports must be sought first of all among the men who were in the service of the Swedish Crown, since it is very unlikely that it would occur to one of the Rosenburg sons, for example, to send reports to Swedish officials in Narva or other places on their own initiative. One person who would seem to be a good candidate in this context is the "correspondent" Christoffer Kochen (1637-1711) from Reval: he was employed in the Swedish service specifically to write reports from Moscow to the Swedish government. Kochen came to Russia in 1655, at the age of 17-18 years, as the secretary of Johan de Rodes, whose news reports from Moscow, as mentioned above, were not only sent to the Swedish govern-

\footnotetext{
54 The year 1651 is according to Munthe $(1935,142)$; other sources give his appointment as dating from 1649, with his arrival in Moscow in 1650 (see the summary in Ellersieck 1955,51 , footnote 47 ).
} 
ment, but can also be traced in the Hamburg press (Welke 1976, 152-153, 255-264). (The contacts between the two were strengthened through the marriage of Kochen's sister, Medea, to de Rodes. $)^{55}$ It is also possible that Kochen sent a report either directly to the Hamburg paper or to a newspaper agency; he would have had many press contacts through his (late) brother-inlaw de Rodes. Kochen is not mentioned by name in any of our sources, so it is impossible to say whether or not he was actually present at the performance, but his long experience in Moscow makes him a good possible candidate as one of our informants. Even if he was not personally invited to attend the presentation, he might still have written a report on the basis of an oral account by one of the "actors", and it would, of course, have been very easy for him to supply the additional political information (for instance, about the Polish ambassadors).

Whereas we thus do have reasonable potential authors for sources 2 and 3 (Butenant and Kochen), we cannot offer a candidate for our longest and most interesting source, number 4 . He mentions many names; the only participant that was not given a name or, at least, a function (such as "Mr. Butenant's house teacher", or "the embassy's honourable former stable master") is the author himself. We still hope to solve this mystery, but for the moment we do not have an answer.

\section{Conclusion}

This series of reports, clustered in the last weeks of February and the first days of March 1672, allows us to clarify the early history of the Muscovite theatre. We can now understand that Tsar Aleksej's famous court theatre, which opened in October 1672, was the result of a very specific set of performances, given by a group of foreign residents for the royal family (including the women) and a limited audience that included some highly-placed advisors and at least one foreign spectator (Butenant). In revealing the details of this performance, we have been able to clarify one of the most important documents describing Muscovite cultural life - Rautenfels' De Rebus Moschoviticis, which has long been cited in the context of the theatre but has never been fully understood. In addition, the diplomatic reports we cite above show how important such sources are not just in the context of political history, but for

55 See Elgenstierna 1934, 338. For more information about Christof(f)er von Kochen see Svenskt biografiskt handlexikon (1906, 602-603). 


\section{Claudia Jensen, Ingrid Maier}

our understanding of Muscovite culture as well. Finally, these events reinforce the important ties between the residents of Moscow's Foreign Quarter and the new cultural trends of Tsar Aleksej's last years; more specifically, Matveev obviously knew exactly where to find appropriate performers, organizers, singers, and writers to call upon for quick action.

It is also worth noting the overall similarity among all our accounts; the single exception is in the descriptions of the structure from which the royal women viewed the performance. Whereas all of the other reports have the women peering through a curtain or sitting in some sort of fabric enclosure, Rautenfels describes them looking through wooden slits to watch the performance. Since Rautenfels' account, unlike the other reports, was written several years after the event, it is possible that the details were hazy in his mind. At any rate, the overall uniformity of these various accounts leaves no doubt that each of the authors was describing the same event.

Our work has important implications for further study of the Russian court theatre. First, because we know the specifics of this initial "ballet" entertainment, we can now examine the court plays themselves in a new light. To take one obvious example, Pickleherring appears, either by name or by characteristic actions, in later plays in the court repertoire - based on the popularity of this figure in the February performances, it is now easy to see why. Furthermore, the very use of the term "ballet" will help us understand the nature of the later productions that appear in the final period of Tsar Aleksej's court theatre (see, e.g., Bogojavlenskij 1914, 57). As we have learned from the documents examined here, although dance may have been a component of such "ballets", they are certainly not to be understood as an evening's entertainment made up primarily of dance, but rather as a miscellany of short acts and performances.

Our discoveries will contribute to an understanding of Western theatrical traditions and assumptions as well. The foreign performers were all amateurs, quickly putting together this series of skits and vignettes based on their own shared experiences. The result - Orpheus, Mercury, Pickleherring, and all the rest - thus provides a snapshot into what average Westerners (and, specifically, those from German-speaking territories) considered to be normal and, perhaps equally important, reproducible. We also get a better idea about the music-making in the Foreign Quarter, for the actors used the instruments they knew how to play and happened to have with them on their posting in far-away Moscow. Finally, we know (from the two newspaper articles and 
from the details that filled the diplomats' reports) that this event was of interest not just to court and diplomatic circles in the West, but even to the readers of newspapers in Hamburg, Haarlem, and possibly Amsterdam.

We will take up some of these issues in our forthcoming article, in which we will also answer an additional question raised by the sources surveyed here. The February show was obviously hugely popular, and we know that additional performances were put on hold due to the death of the patriarch as well as the beginning of the Lenten fast. ${ }^{56}$ Were there any others? As we will show, the delights of the experience with Pickleherring and his fellow entertainers were not easily forgotten. An encore performance, in May 1672, was not only expanded in scope, but proved to be the immediate catalyst for the planning to begin in earnest for the "official" court theatre in Moscow.

\section{Acknowledgments}

The authors thank Jürgen Beyer, Heiko Droste, Hans Helander, Martha Lahana, Anke Martens, and Winfried Schumacher for their contributions to this article. We also thank Sabine Dumschat, Lidija Sazonova, Evgenij Vorob'ev, Emmanuel Waegemans, Daniel Waugh, and - last but not least - an anonymous reviewer, who read earlier drafts of this work and made valuable suggestions.

\section{Sources}

\section{Hand-written primary sources}

At the National Archives (Riksarkivet, RA), Stockholm:

Livonica II, vol. 180.

Bengt Horn collection, E 4304.

Printed primary sources

Nordischer Mercurius. 1672. Martius. [Hamburg: Georg Greflinger.]

Oprechte Haerlemse Saterdaegse Courant. 1672. No 15. Haarlem: Abraham Casteleyn. Reutenfels [Rautenfels], Jacobus. 1680. De Rebus Moschoviticis ad Serenissimum Magnum Hetrurice Ducem Cosmum Tertium. Padua: Typis Petri Mariae Frambotti.

56 The patriarch died on 17 February, but even if he had lived, the performances could only have been repeated once, on the following day, due to the beginning of the Lenten fasting period. 


\section{Claudia Jensen, Ingrid Maier}

\section{References}

Amburger, Erik. 1956. "Die Mitwirkenden bei der Moskauer Aufführung des 'Artaxerxes' am 17. Oktober 1672”. Zeitschrift für slavische Philologie 25:304-309.

. 1968. Die Anwerbung ausländischer Fachkräfte für die Wirtschaft Rußlands vom 15. bis ins 19. Jahrhundert (Osteuropastudien der Hochschulen des Landes Hessen. Reihe 1, Gießener Abhandlungen zur Agrar- und Wirtschaftsforschung des europäischen Ostens, vol. 42). Wiesbaden: O. Harrassowitz.

Artakserksovo dejstvo. 1957. Artakserksovo dejstvo - pervaja p'esa russkogo teatra XVII v. Podgotovka teksta, stat'ja i kommentarii I. M. Kudrjavceva. Moscow: Izdatel'stvo Akademii nauk SSSR.

Beyer, Jürgen. 2012. "Stiftung, Plazierung und Funktion von Wand- und Kronleuchtern in lutherischen Kirchen”. Zeitschrift für Lübeckische Geschichte 92: 101150.

Brikner, A. 1884. "Lavrentij Ringuber”. Žurnal ministerstva narodnogo prosveščenija 2 $\left(\right.$ Fevral'$\left.^{\prime}\right): 396-421$.

Bogel, Else and Elger Blühm. 1971. Die deutschen Zeitungen des 17. Jahrhunderts. Ein Bestandsnachweis mit historischen und bibliographischen Angaben, vol. 1. Bremen: Schünemann Universitätsverlag.

Bogojavlenskij, S. K. 1914. "Moskovskij teatr pri carjach Aleksee i Petre”. Čtenija v Imperatorskom obščstve istorii i drevnostej rossijskich pri Moskovskom universitete. Kniga 2-ja, č. I, III-XXI: 1-76.

—. 1946. Prikaznye sud'i XVII veka. Moscow: Izdatel'stvo Akademii nauk SSSR.

Cholodov, Efim Grigor'evič. 1983. "K istorii starinnogo russkogo teatra (neskol'ko utočnenij)". Pamjatniki kul'tury. Novye otkrytija 1981, 149-170.

—2000. Teatr i zriteli. Stranicy istorii russkoj teatral'noj publiki. Moscow: Gosudarstvennyj institut iskusstvoznanija.

Crummey, Robert O. 1983. Aristocrats and Servitors: The Boyar Elite in Russia 16131689. Princeton: Princeton University Press.

Das Grosse und mächtige Reich. 1687. Das Grosse und mächtige Reich Moscovien [...]. Nuremberg: Johann Lochner.

Dumschat, Sabine. 2006. Ausländische Mediziner im Moskauer Rußland. Quellen und Studien zur Geschichte des östlichen Europa, vol. 67. Stuttgart: Steiner. .2011. “Coster (Köster) von Rosenburg, Johann(es)”. Biographisches Lexikon für Schleswig-Holstein und Lübeck, Band 13, n.d. [2011], n.p. [Neumünster]: Wachholtz, 112-116.

Dünnhaupt, Gerhard. 1991. Personalbibliographien zu den Drucken des Barock. Dritter Teil: Franck - Kircher. Stuttgart: Hiersemann. 
Elgenstierna, Gustaf. 1934. Den introducerade svenska adelns ättartavlor, vol. 8. Stockholm: Norstedt.

Ellersieck, Heinz. 1955. Russia under Aleksei Mikhailovich and Feodor Alekseevich, 1645-1682: The Scandinavian Sources. Ph.D. dissertation, University of California. Los Angeles.

Findeizen, Nikolai Fedorovich. 2008. A History of Music in Russia. Translated by William Pring; edited by Miloš Velimirović and Claudia Jensen, with the assistance of Malcolm Hamrick Brown and Daniel Clarke Waugh. 2 vols. Bloomington: Indiana University Press.

Findejzen, Nikolaj Fedorovič. 1928. Očerki po istorii muzyki v Rossii. 2 vols. Moscow: Gosudarstvennoe izdatel'stvo Muzsektor.

Günther, K. 1968. "Das Weimarer Bruchstück des ersten russischen Dramas 'Artaxerxovo dejstvo' (1672)”. Studien zur Geschichte der russischen Literatur des 18. Jahrhunderts. Band 3. Berlin. Veröffentlichungen des Instituts für Slawistik, vol. $28,120-178$.

Hildebrand, Bengt. 1945. "Ebersköld, Adolph". Svenskt biografiskt lexikon. Elfte bandet: de la Grange - Ebersköld. Stockholm: Svenskt biografiskt lexikon, 777-780.

Hoffmann von Fallersleben, August Heinrich. 1855. "August Buchner". Weimarisches Jahrbuch für deutsche Sprache, Litteratur und Kunst 2:13-38.

Jensen, Claudia. 2009. Musical Cultures in Seventeenth-Century Russia. Bloomington: Indiana University Press.

Jensen, Claudia and Ingrid Maier. Forthcoming. "Pickleherring in the Kremlin: More New Sources on the Pre-History of the Russian Court Theatre".

Koch, Ernst. 1911. "Die Sachsenkirche in Moskau und das erste Theater in Rußland”. Neues Archiv für sächsische Geschichte und Altertumskunde 32:270-316.

Kotošichin, Grigorij. 1980. Grigorij Kotošixin. O Rossii v carstvovanie Alekseja Mixajloviča. Text and commentary A. E. Pennington. Oxford: Clarendon Press.

Limon, Jerzy. 1985. Gentlemen of a Company: English Players in Central and Eastern Europe, 1590-1660. Cambridge: Cambridge University Press.

Lichačev et al. 1984. D. S. Lichačev, A. M. Pančenko and N. V. Ponyrko. Smech v drevnej Rusi. Leningrad: Nauka.

Louria, Yvette. 1968. “The Comedy of Artaxerxes (1672)". Bulletin of the New York Public Library 72, no. 3:139-210.

Maier, Ingrid. 2004. "Niederländische Zeitungen ('Couranten') des 17. Jahrhunderts im Russischen Staatsarchiv für alte Akten (RGADA), Moskau”. GutenbergJahrbuch 79:191-218.

Martens, Anke. 1999. Hamburger Kaufleute im vorpetrinischen Moskau. Hamburger Beiträge zur Geschichte der Deutschen im europäischen Osten, vol. 6. Lüneburg: Nordostdeutsches Kulturwerk. 
2001. "Heinrich Butenant - Hamburger Kaufmann und Unternehmer in Moskau, Diplomat und Vertrauter Peters des Großen”. In Kollektivität und Individualität. Der Mensch im östlichen Europa. Festschrift für Prof. Dr. Norbert Angermann zum 65. Geburtstag, edited by Karsten Brüggemann et al. Studien zur Geschichtsforschung der Neuzeit, vol. 23. Hamburg: Kovač, 119-171.

Mazon, André and Frédéric Cocron. 1954. "La Comédie d'Artaxerxès" (Artakserksovo dejstvo) présentée en 1672 au Tsar Alexis par Gregorii le Pasteur. Paris: Institut d'Études slaves de l'Université de Paris.

Munthe, Carl Arne. 1935. “Utrikesförvaltningen 1648-1720". In Den svenska utrikesförvaltningens historia, edited by Sven Tunberg et al. Uppsala: Almqvist \& Wiksell, 109-210.

Paul of Aleppo. 1834. The Travels of Macarius. Translated by F. C. Balfour. Vol. 2. London: Printed for the Oriental Translation Committee.

Pervye p'esy. 1972. Pervye p'esy russkogo teatra. Pod redakciej A. N. Robinsona. Rannjaja russkaja dramaturgija, XVII - pervaja polovina XVIII v. Moscow: Nauka.

Proehl, Friedrich-Karl. 1962. "Eine Beschreibung Moskaus durch den Kurländer Jakob Reutenfels”. Zeitschrift für Ostforschung. Länder und Völker im Östlichen Mitteleuropa 11:455-475.

Relation. 1669. A Relation of Three Embassies from His Sacred Majestie Charles II to the Great Duke of Muscovie, the King of Sweden, and the King of Denmark. Performed by the Right Ho-ble the Earle of Carlisle in the years 1663 and 1664. London: Printed for John Starkey.

Reutenfels [Rautenfels], Jacob. 2003. De Rebus Moschoviticis ad Serenissimum Magnum Hetrurice Ducem Cosmum Tertium. Reprint, edited by Marshall Poe. Early Exploration of Russia, vol. 11. London and New York: RoutledgeCurzon.

Ries, Paul. 1977. "The Anatomy of a Seventeenth-Century Newspaper”. Daphnis 6, 1-2:171-229.

Rinhuber, Laurent. 1883. Relation du voyage en Russie fait en 1684 par Laurent Rinhuber. Publiée pour la première fois d'après les manuscrits originaux qui se conservent à la bibliothèque ducale publique de Gotha. Berlin: Albert Cohn.

Robinson, A. N. 1974. Bor'ba idej v russkoj literature XVII veka. Moscow: Nauka. . 1976. "Pervyj russkij teatr kak javlenie evropejskoj kul'tury”. Novye čerty $v$ russkoj literature i iskusstve (XVII - načalo XVIII v.). Moscow: Nauka, 8-27.

Schellenberger, Jürgen. 1993. Die Sprache des Artakserksovo dejstvo: Studien zur sprachlichen Situation im Rußland des ausgehenden 17. Jahrhunderts. Slavistische Beiträge, vol. 301. Munich: Otto Sagner.

Schlegel, Bernhard and Carl Arvid Klingspor. 1875. Den med sköldebref förlänade men ej å riddarhuset introducerade svenska adelns ättar-taflor. Stockholm: Norstedt. 
Skazanija 1905. 'Skazanija svetlejšemu gercogu toskanskomu Koz'me tret'emu o Moskovii”, Čtenija v Imperatorskom obščstve istorii i drevnostej rossijskich pri Moskovskom universitete. Kniga 3-ja, č. 2:I-X, 1-128.

Skazanija 1906. 'Skazanija svetlejšemu gercogu toskanskomu Koz'me tret'emu o Moskovii", Čtenija v Imperatorskom obščestve istorii i drevnostej rossijskich pri Moskovskom universitete. Kniga 3-ja, č. 3:129-228.

Skazanija 1997. "Skazanija svetlejšemu gercogu toskanskomu Koz'me tret'emu o Moskovii”. In Utverždenie dinastii, edited by A. Liberman, 231-406. Istorija Rossii i doma Romanovych v memuarach sovremennikov XVII-XX vv. Moscow: Fond Sergeja Dubova.

SRJa XI-XVII. 1989. Slovar' russkogo jazyka XI-XVII vv., vol. 15. Moscow: Nauka. Stensen, Niels [=Steno, Nicolaus] et al. 1952. Nicolai Stenonis epistolae et epistolae ad eum datae. Edited by G. Scherz and J. Ræder. Copenhagen: Nyt Nordisk Forlag. Svenskt biografiskt handlexikon. 1906. Svenskt biografiskt handlexikon. Alfabetiskt ordnade lefnadsteckningar af Sveriges namnkunniga män och kvinnor från reformationen till nuvarande tid. Förra delen, $A-K$. Stockholm: Bonnier.

Tering, Arvo. Forthcoming. Lexikon estländischer, livländischer und kurländischer Studenten an europäischen Universitäten 1561-1800, edited by Jürgen Beyer. Quellen und Studien zur baltischen Geschichte. Cologne: Böhlau.

Veluwenkamp, Jan Willem. 2000. Archangel: Nederlandse ondernemers in Rusland 1550-1785. [Amsterdam]: Uitg. Balans.

Welke, Martin. 1976. "Rußland in der deutschen Publizistik des 17. Jahrhunderts (1613-1689)". Forschungen zur osteuropäischen Geschichte 23:105-276.

_. 1985. "Deutsche Zeitungsberichte den Moskauer Staat im 17. Jahrhundert". Russen und Rußland aus deutscher Sicht. 9.-17. Jahrhundert. West-östliche Spiegelungen, series A, vol. 1. Munich: W. Fink, 264-286.

\section{Appendix}

We transcribe our sources as exactly as possible. The distribution of the letters $u / v$ and the punctuation of the originals have been preserved. New lines are not marked; new pages are marked with the sign ||. In the Latin text (source 1), all supralinear signs used in the printed book are reproduced; $e$ caudata is rendered as ae (e.g., Musicae). In the German-language verses to the tsar, we have substituted the characters and letter combinations $\mathfrak{a}, \hat{o}, i i / \hat{u}$, and $v v$, which were used in the 1680 edition, with the normal German letters $\ddot{a}, \ddot{o}, \ddot{u}$, and $w$ (which apparently were unavailable at the printing shop in Padua); for the rest we have kept the spelling of the original, including non-standard use of uppercase and lowercase letters. Two obvious printing errors were corrected (in square brackets).

The German-language manuscript documents (sources 3 and 4), originally written in Gothic style (Frakturstil), are rendered in Roman letters, whereas whole words and parts of 


\section{Claudia Jensen, Ingrid Maier}

words written in Latin letters in the originals are rendered in italics; other queries relating to specific letters, comments, and abbreviations are given in square brackets.

\section{Source One}

Idemque proxime retroactis annis scenam saltatoriam, necnon Ahasveri, \& Estherae historiam, comicè descriptam, prae ||sentari sibi ab exteris, Moscuae degentibus, sustinuit. Cùm enim ex nuntiis passim intellexisset, Europae Principibus varios interdùm ludos, choreas, aliaque delectamenta, ad fallenda temporis fastidia, exhiberi, specimen eius rei in tripudio aliquo Gallico derepentè fieri iussit. Vndè temporis angustiâ sic definiente, intra septiduum omne choragium, quâ potuit festinatione, est confectum. Quod ut ut extra Moschoviam sine anticipata dedecoris venia spectari non potuisset, Russis tamen singulare, \& artificiosum apparuit: quippe quibus \& nova vestimentorum monstra, \& theatri insolita facies, ipsumque magnificum peregrinitatis nomen, \& inauditae modulationes Musicae, admirationem facile pepererunt. Equidem initiò Zarus instrumenta Musica adhiberi, utpotè rem novam, \& profaniorem, nolebat. Ast, cùm ità choream sine Musica, quemadmodùm sine pedibus ritè institui non posse saltatores, causarentur, omnia ipsorum arbitrio peragenda, ferè invitus, reliquit. Mimum totum ipse Zarus ante theatrum, in sella considens, Zariza vero cum liberis regiis per transennam, seu rimas potiùs, ex tabulatis e regione dispositis, clausisque spectarunt: at Proceres, reliquis omnibus abesse iussis, in scenis constitêre. Elogium Zari, quod Orpheus, antequàm duas inter ambulatorias pyramides saltare inciperet, cecinit, rude licèt, atque inconditum, laudatissimi tamen Alexii causâ, hìc censui recitandum. ${ }^{57}$

1 .

ISt nun der gewünschte tag

Dermahl eins erschienen,

Das man dir zur freude mag,

Grosser Zare dienen?

2 .

Vnser unterthänigkeit

Mus $\mathrm{Zu}$ deinen füssen

Darthun ihre schuldigkeit,

Vnd sie dreymahl küssen.

3.

Gros ist zwar dein fürstenthum,

Das dein witz regieret,

Grösser doch der tugendruhm

So dich höher fihret.
4.

Dein verstandt und helden macht

Kan uns zubereiten,

Nach der langen kriegesnacht, Guldne friedenszeiten.

5 .

Das gerechte straffgericht, Vnd zugleich die güte, Machen durch ihr himmelslicht, Göttlich dein gemüthe.

6.

So muss deine treffligkeit

Sich dem himmel gleichen, Weil dir noch zu unster [=unsrer] zeit

Alle müssen weichen.

57 This poem also appears in the German book Das Grosse und mächtige Reich ... (1687, 109-110), in the Russian translation of the Padua edition from 1680 (Skazanija 1905, 89), 
7.

Du der Reussen helle Sonn,

Mit dem Mond und Sternen,

Lebet stets in höchster wonn, Vnglück steh von fernen!

8.

Hersche lang, o himmelsfreund,

Misgunst du must schweigen,

Welche Gott so nahe seind,

Müssen wol gedeigen!
9.

Drumb wolam [=wohlan] mein seyten werck, Las dich lieblich zwingen, Vnd du Pyramidenberg, Hupfe nach dem singen!

Eodem die quippe Bacchanalium ludorum penultimo, venationem pariter in fluvio Mosqua, glacie concreto, Zarus edidit, ubi vegrandes Britannici, aliusq; generis canes cum candidis illis ursis Samoiedicis, quò magis fallentibus lubrico super pavimento vestigiis, eò etiam iucundiore spectaculo decertarunt. Vesperi autem ad volatiles pyrobolorum ignes, in eadem glacie spectandos, abiit.

Reutenfels 1680, 104-107 (Uppsala University Library)

\section{Source Two}

Moßkau vom 23. Februarii.

In publicis geschieht alhier wenig. Die Polnische Herren Gesandten vermindern ihre Suite sehr/ und sind jüngst noch 30. Personen mit einer Polnischen Leichen fortgegangen/ so sollen auch morgen in 40. meist vom Adel/ fort wollen/ werden also nur drey der Vornehmsten alhier verbleiben/ von derer Verrichtung doch wenig sonderliches vermuhtet wird. Seine Czarische Majestät haben sich vor der Fasten mit Bären-Hätzen/ Feuerwercken/ und dergleichen belustiget. Am 16. dises haben auch 12. Deutsche vor Ihrer Czar. Maj. in Dero Herrn Schwigervater/ Ilia Danielowiz Palatio ein Ballet gepräsentirt/ es bestundte von 4. Romanern/ 4. wilden Männern/ 2. trunckenen Bauern/ und 2. Beutelschneydern/ denen noch ein lustiger Pickelhering zugefüget wurde. Das Theatrum war sehr köstlich/ und saß Seine Czarische Majest. mit Dero 4. Prinzen und größesten Ministris nicht weit davon. Die Czarin oder Käyserin aber saß mit ihren Stats-Dames hinter || einer Scharlacken-Decken/ welche doch also beschaffen war/ daß man Dero Schönheit/ und Sie das Ballet wohl sehen kunnten. Sie leuchteten/ wie die hellen Sterne/ aus kleinen Wolcken/ hervor/ und weilen dises Ballet das erste war/so jemals in Moßkau ist gesehen worden/gab es derowegen große Auffsicht. Der Czar mit seinen 4. Prinzen und Großen/ also auch die Czarin mit den Ihrigen waren hierüber so frölich/ daß sie auch offtmals fast ein Leib-erschütterndes Gelächter bezeigten/ und nach deßen Endigung solches am folgenden Tage nochmals zu präsentiren begehrten. Am Morgen aber des folgenden Tages starb der Patriarch/ damit wurde sol-

and even in Mazon and Cocron (1954, 46-47), since these authors thought that the verses belonged to the Esther play, performed in October 1672. 
ches/ biß Ostern/ außzusetzen begehret. Die Ballet-Halter wurden mit Wein und Meht beschencket/ welches alhier eine große Gnade ist; So war auch die Hoffnung/ einige Czarische Geschencke/ sonderlich von Zobeln/ zu empfangen/ an welcher Gnade auch noch nicht zu zweiffeln ist. Die Music war von 2. Violen/ 1. Viol di Gambe/ und 2. singenden Stimmen/ welche/ wie man vermärckte/ das Frauenzimmer/ als eine ungewohnte Music/ sehr belustigte. Dises wird darum geschriben/ um hierauß zu sehen/ daß das/ was bey unsern Deutschen gantz gemein ist/ an disen Orten was neues sey.

Nordischer Mercurius, Martius 1672, 197-198

(Uppsala University Library, Hist. tidskr.)

\section{Source Three}

Mosco den 20.t[en] Februarÿ. Ao 1672.

Den 17. dieses hat der hiesige Patriarch Joseph, ungefehr die glocke 8. des morgens diese welt gesegnet, seines alters von 84. Jahren, an deßen stelle man vermuhtet, daß gegen Ostern ein anderer werde erwehlet bleiben. Vergangenen Freÿtag haben Ihre Zaarische Mtt:, dero Gemahlin, und gantze familie ein ballet /:so von 12 Personen meist außlendischen Kaufleuten gehalten, u. worvon des Doctor Rosenburgs Sohn, so neulich hier ins Landt gekommen, der autor war:/ angesehen, und hat solches Ihrer Zaarischen Mtt: sehr wohl gefallen. Selbige saßen gantz nahe darbeÿ, und bloß, das FrauenZimmer aber hinter einer roht Lacken gvardien verdecket, jedoch daß man ihre Angesichter vollenkommen sehen könte; wie das ballet zum ende wahr, ließen Ihre Zaarische Mtt. sich bedancken, und darbeÿ sagen, daß man den andern tag gegen den abend wieder kommen solte, weil aber der Patriarch den folgenden tag mit Todte abgangen, blieb es nach; Man verwundert sich, daß Ihre Zaarische Mtt: nebst dero gantzen familie solches angesehen, weil vor diesem dergleichen anzuschauen, niemalen ist zugelaßen worden. Ihre Zaarische Mtt. u. das FrauenZimmer lächelten offtermals daß man es hörte, insonderheit uber des Pickelherings poßen und minen: beÿ dem gantzem Wesen, so uber 3. Stunden wehrete, ward nichts geredet, nur daß des Doctor Rosenburgs Sohn, den Anfang und das Ende || mit einer Teutschen Rede an Ihre Zaarische Mtt. richtete; die Kleider haben ungefehr 200. Rubl. gekostet; das Theatru[m] war mit Teppichten, und grunem Lacken bezogen. Vergangene woche wahren die Pollnischen Gesandten abermahl zur conferentz, haben aber nichts geschloßen; ihr expresser, welcher mit einigen Punkten, so die hiesigen von ihnen begehren, an den König gesandt worden, ist noch nicht wieder zu rucke kommen; unterdeßen reÿsen viel Edelleute von ihrer Mitte wieder nach Pohlen; vor einigen tagen ward ein Edellman, nahmens Stabrofskij, der allhier todes verblichen, mit 30. Personen fortgesandt, so sind auch noch heute uber 40. Personen, meist Edelleute zu rucke gangen, daß also die principalen mit wenig Volck, bis weitere ordre, annoch hie verharrn. Diese woche halten die Reußen sich zu hause, reinigen und bereiten sich zu ihren fasten.

RA Stockholm, Bengt Horn collection, E 4304 


\section{Source Four}

Extract Schreiben von Muscow.

Sonsten ist seÿder des Herrn abreise weinig Notabels vorgangen maßen Ihre Tzarsche Mä̈:tt in dieser Fastenzeit, sich haben allerhandt lustigkeiten vortragen laßen, Nemlich mit Berenhitzen, feuerwercke, undt zum letz mit ein groß ballet, so wihr unter Unß 12. Personen dergestalt, sonder ruhm zu melden aufm Schloß in des Tzaren Schwiegermutters [!] Ilian Danilowitz behausung gepresentiret daßes seine Maÿ:tt nebst deßen Gemahlin, mit die Princessinnen undt die Herren ReichzRäthen mehr als gemeine contentiret hat, Ihre Tzarsche Maÿ:tt saßen offendtlich vor daß Theatrum, dito daß besagte Königl[iche] Frawen Gezimmer, welche aber mit rodt laaken beschantzet wahren, alleine sie Schnitten alßbaldt so große löcher darein da sie durchsehen könten, der Tzar war in sehr lustiger humeur, daß Theatrum war von grünen Laken, wie auch mit goldt leder außgezieret, zu dero mitte wahr ein Köstlicher groß Spiegel, die floor wahr mit sehr schönen Tappetzeraÿen bekleidet wihr hetten zu solcher vortsetzung schöne Aseaschen undt rodt Kindiaken, alß auch Taften Kleider, welches Ihre Maÿ:tt vor Contant auß die Cramen kauffen undt nach der römerschen art durch 25 . schneiders vorfertigen laßen vndt wahren in diesem Ballet folgende Personen Nemlich Doctor Rosenborg seine beÿden sohne, als auch deßen studiosus Mons: Trautenberg, Herr Butinant sein studiosus, beÿde Herrn Siwerts der Elteste Brüder war Inventor undt angeber, Negst dem Mons: Rosenburg der sein Person vor 4. Agirte, Nemlich vor Mercurius, Orpheus, Ein Moohr, viertens vor Ein Willman, Mons: Christo[ffr] Roden war Jäger in Grüne Saffen kleider, Nebst 3. andern als Rautenberg undt Hasenkrach, der sonsten mit ein artiger Pickelherung war, Paridon Voos, Mons: Hindrich M[ü]nter, Mons: Fabbert, Alß auch der gewehsene Ehren||vester Legation Stallmeister, welcher als ich, mit Mons: Münter zweÿ willde Männer, undt nach dem zweÿ drumbene Bauren Agirten Trummelten aufs Theatrum, da solte der Herr Curiose Luft Sprünge gesehen haben, darvon der Herr Butenandt ims kunftig Attestiren kan, dem wir pro forma mit ein Axal gaben das Er es mit anzusehen krigte, sonsten wart starke wacht gehalten, daß keine könte einkommen ohne die große Baiaren als Arctemon Czergowitz Trokunow, undt dergl: die unsens Theatrum sehr bewanten. Es gefillen Ihre Maÿ:tt Nebst die hochgedachten Frawen Gezimmer so woll daß Sie unterschiedner Mahlen solachten, daß Sie sich schuttelten, insonderheit der Tzar. Vndt hatten sie so große patientz daß Sie über dreÿ Stunden mit größester vergnügung Saßen auch bewilligten Sie unß die Musick alß zweÿ Fiolen, Ein Fioligam undt fleutz, alß auch dwer fleutz, da es nun geendiget wahr, Lißen Ihre Tzarsche Maÿ:tt vnß semtlich durch Herr Artemon Sergowitz bedancken, und versuchten, daß wihr als des andern tages wieder in solche Positur mögten erscheinen, so wihr auch umb Ihre Tzarsche Mä̈:tt zu gehorsam acceptirten, deß Andern morgens starb der Patriach [sic!] zu unsern Schaden, in dem Ihre Tzarsche Maÿ:tt vnß eine köstliche begnadigung zugedachten hatten, Auff Ostern werden wihr zweifels ohne die continuation geben müßen; Alßdan durfte es folgen. Hierbeÿ ergehet daß liedt welches von Mons: Hinrich Münter beÿ selbiger act, Mit einer Fioligam darein stümmendt, sehr liblich gesungen wardt, daß ist fürwahr dieses ortes waß rares undt sonderlich was neues, weilen es alhier vor diesem niemahln erhöret, dieses passirte den 16. stantio, zur anfenglichen praesent in selbigen Bal- 


\section{Claudia Jensen, Ingrid Maier}

let war einer verthönung perspectiv=weis, des Doctors sein Sohn in sehr prechtigen Kleider auf ein Stul sitzendt, sage stehendt Mercurius mit flügelln an Kopf undt füßen, vor ein Berg || von Grenen wolgemacht und hinter den berg stieg hervor ein dobbelter rodt gemalter Adler undt daß beÿ licht, wohrbeÿ sich dan zwei perimiden berg sehr kostlich sehen lißen, ich undt münter als zweÿ wilde Männer standen vor die thür mit zu schlagende Keuhlen auf dem Nacken gegen ein ander, in summa es war wahrlich artig und gieng alles glücklich von staten, Ihre Tzarsche Maÿ:tt hetten noch gerne geseßen undt es ferner angesehen, aber Wihr hetten nichts mehr übrig zu agiren, Vber den Pickelherung undt dieser Heinrich Ballon Lachten Seiner Tzarscher Maÿ:tt sehr der Pickelhering war Hasenbruch, undt der ander war balbier Alß auch zur letz über dz Schatten werck, welches sehr artig kam, gott lob daß es seiner Maÿ:tt undt die ubrigen zuseher so woll gefallen; Anlangendt die Polnische Gesandten so befinden dieselben sich noch alhier, undt vormindern täglich Ihre Suite, in Abfertigung nacher Pohlen, vor 14. tagen haben sie einen Edellman mit nahmen Stabrocosckÿ von allhier mit 30 Man, welcher Stabrocosckÿ hier gestorben, Auch Abgesandt, Vor 3. tagen gingen noch beÿ 40. Personen weg, welche mehrentheils auch Adel seindt. Inn kurtzen wirdt der homar mit ein Suite ihnen folgen, Vndt verbleiben also nuhr die 3. principalen mit einige derer Bedienten, biß auf weiter bescheidt zu kegen, Noch zur zeit haben Sie weiniger nichtes zur sachen vorrichtet, Sie warten auf Ihren expressen welcher mit einiger Punchten von Ihro Tzarschen Maÿ:tt an Ihrem König Abgefertiget së̈; deßen Resolution hat man zu Gewarten: Man saget Stoncka Raisen sein bruder soll von Beren zeweÿrißen werden.

RA Stockholm, Livonica II, vol. 180

\section{Source Five}

\section{O S S C H O VIE N.}

Muscow den 1 Maert. Desen Vasten-Avondt hebben 12 Duytsen Sijn Czaarsse Majesteyt med een Ballet verlustight/ zijnde het eerste/ dat hier gesien is: doch wanneer het des anderen daegs weer soude gedanst werden/ overleet den Patriarch/ en bleef alsoo achter. De Poolsse Afgesanten/ hier slechte verrichtingen hebbende/ verliesen alle haer Volck/ die te rugge keeren.

Oprechte Haerlemse Saterdaegse Courant No 15, 1672, p. 2 (Nat. Archives Kew, SP 119/62, fol. 43) 